Ye. Yu. Zudova, O. P. Khvorost

National University of Pharmacy of the Ministry of Health of Ukraine

\title{
The study of the elemental composition of common domestic types of the medicinal plant raw material
}

Aim. To determine the elemental composition of common domestic types of the medicinal plant raw material, such as Sophora japonica flower buds, Crataegus sanguinea leaves and flowers, Astragalus dasyanthus herb, Mentha piperita leaves, Arctium lappa roots.

Materials and methods. The elemental composition was studied by atomic absorption spectrography with photographic registration. The research was conducted at the premises of STC "Institute of Single Crystals" of the National Academy of Sciences of Ukraine (Kharkiv).

Results and discussion. The results of the research obtained show that the samples of common domestic types of the medicinal plant raw material studied contain at least 19 chemical elements; potassium, calcium, magnesium, and phosphorus predominate among them.

Conclusions. The study shows the prospects of creating new original complex drugs from the raw material of the plants studied for the prevention and treatment of diseases of the cardiovascular system, in particular hypertension.

Key words: mineral compounds; Sophora japonica flower buds; Crataegus sanguinea leaves and flowers; Astragalus dasyanthus herb; Mentha piperita leaves; Arctium lappa roots

\section{Є. Ю. Зудова, О. П. Хворост}

Національний фрармацевтичний університет Міністерства охорони здоров'я України

\section{Дослідження елементного складу популярних вітчизняних видів лікарської рослинної сировини}

Мета дослідження. Визначити елементний склад поширених вітчизняних видів лікарської рослинної сировини: пуп'янків софрори японської, листя та квіток глоду криваво-червоного, трави астрагалу шерстистоквіткового, листя м'яти перцевої та коренів лопуха звичайного.

Матеріали та методи. Дослідження елементного складу виконували методом атомно-абсорбційної спектрографії з фотографічною реєстрацією на базі НДУ НТК «Інститут монокристалів» НАН України (м. Харків).

Результати та їх обговорення. Отримані результати свідчать, що в досліджуваних зразках поширених вітчизняних видів лікарської рослинної сировини міститься не менше 19 хімічних елементів, серед яких превалюють калій, кальцій, магній, фоосфор.

Висновки. Проведене дослідження доводить перспективність створення з сировини зазначених рослин оригінальних комплексних лікарських засобів для профрілактики та лікування захворювань серцево-судинної системи, зокрема артеріальної гіпертензії.

Ключові слова: мінеральні сполуки; пуп'янки софори японської; листя та квітки глоду кривавочервоного; трава астрагалу шерстистоквіткового; листя м'яти перцевої; корені лопуха звичайного

\section{Е. Ю. Зудова, О. П. Хворост}

Национальный фрармацевтический университет Министерства здравоохранения Украины

\section{Исследование элементного состава популярных отечественных видов лекарственного растительного сырья}

Цель исследования. Определить элементный состав распространенных отечественных видов лекарственного растительного сырья: бутонов софоры японской, листьев и цветков боярышника кроваво-красного, травы астрагала шерстистоцветкового, листьев мяты перечной и корней лопуха обычного.

Материалы и методы. Исследование элементного состава проводили методом атомно-абсорбционной спектрографии с фотографической регистрацией на базе ГНУ НТК «Институт монокристаллов» НАН Украины (г. Харьков).

Результаты и их обсуждение. Полученные результаты свидетельствуют, что в исследуемых образцах распространенных отечественных видов лекарственного растительного сырья содержится не менее 19 химических элементов, среди которых превалируют калий, кальций, магний, фоосфор.

Выводы. Проведенное исследование показывает перспективность создания из сырья указанных растений новых оригинальных комплексних лекарственных средств для профилактики и лечения заболеваний сердечно-сосудистой системы, в частности артериальной гипертензии.

Ключевые слова: минеральные соединения; бутоны софоры японской; листья и цветки боярышника кроваво-красного; трава астрагала шерстистоцветкового; листья мяты перечной; корни лопуха обычного 
Introduction. Macro- and microelements (which perform various functions [1], including the role of the plastic material, maintenance of osmotic pressure [2], $\mathrm{pH}$, the ionic and acid-base balance [3,4]) are found in the medicinal plant raw material and their extracts in an organically bound form, which is more suitable for assimilation by a macroorganism [5].

Trace elements, which are part of enzymes, hormones, vitamins and other biologically active substances, are involved in the metabolism of proteins, fats and carbohydrates, growth and reproduction [6, 7]. Impaired absorption of macro- and microelements due to gastrointestinal diseases, increased loss in infectious diseases, burns, blood loss, metabolic disorders in endocrine diseases can lead to the development of new diseases, including cancer, cardiovascular and other diseases [8-10].

According to the World Health Statistics 2021 published by the WHO, hypertension affects approximately $26.5 \%$ of the world's population [11], and this percentage is growing every year. It is one of the most common diseases, which increases the risk of stroke, congestive heart failure, myocardial infarction, peripheral vascular disease and overall mortality. Prophylaxis and early treatment can prevent the development of hypertension and related complications [12]. Treatment options include a diet and lifestyle changes (including the weight loss, smoking cessation, and the increased physical activity), antihypertensive medicines, and surgery in special situations.

Clinical and population studies show that some nutrients, such as sodium, potassium, calcium, magnesium, and fiber, affect blood pressure, and the change in these nutritional factors provides an important strategy for controlling blood pressure, especially in people with high blood pressure and early hypertension.

The macronutrient potassium is necessary for the contractile activity of the heart muscle, normalization of blood pressure. Potassium deficiency disrupts metabolic processes in the myocardium, electrical instability of the heart muscle occurs, leading to the risk of heart failure, stroke, life-threatening arrhythmias, cardiac arrhythmias $[2,6,13]$.

Calcium deficiency, in addition to the muscle function deterioration, leads to heart problems [7, 14]. Magnesium deficiency is found in $90 \%$ of patients who have suffered a myocardial infarction [14-16].

Thus, mineral compounds play an important therapeutic role in the control of blood pressure and a supporting role in the treatment of a number of diseases of the cardiovascular system.

It would be important to determine the composition of mineral compounds of the types of the medicinal plant raw material widely used in the treatment of these pathologies taking into account the increase in man-made pressure on the environment, which leads to changes in the plant composition and xenobiotics.

Sources of such raw material from the families of Fabaceae, Rosaceae, Lamiaceae and Asteraceae are widespread in Ukraine and used in folk and traditional medicine $[9,17,18]$.
For example, Sophora japonica flower buds contain up to $20 \%$ of rutin, quercetin, kaempferol, ascorbic acid, potassium, magnesium, calcium and other elements. Medicines from Sophora japonica flower buds are used for lower blood pressure, increase vascular elasticity $[19,20]$.

Crataegus sanguinea leaves and flowers are the source of flavonoids, phenolic acids, coumarins, triterpene acids, potassium, magnesium, calcium and phosphorus. Extracts from hawthorn flowers have cardiotonic, hypotensive, sedative, antispasmodic effects (they eliminate tachycardia and arrhythmia) [21, 22].

Astragalus dasyanthus herb contains daziantosides, quercetin and kaempferol derivatives, as well as tannins, coumarins, potassium, calcium and silicon. The infusion of the herb has sedative, antihypertensive and diuretic effects [23].

Mentha piperita leaves are rich in essential oils, including menthol, menthon, piperiton, limonene, $\alpha$-phelandrene, proazulenes, etc., flavonoids, tannins, triterpenoids, potassium, calcium, silicon. It has antispasmodic, sedative, antidiarrheal, choleretic effects, and a weak analgesic effect [24, 25].

Arctium lappa roots contain an essential oil, a bitter, sesquiterpene lactones, flavonoids, inulin, a fatty oil, compounds with sulfur, magnesium, calcium, potassium. Extracts from this raw material are used as diuretics, cholagogues, diaphoretics, metabolic normalizers $[16,26]$.

Today there are no complex medicines from these types of the raw material at the Ukrainian market.

The aim of this work was to determine the elemental composition of common domestic types of the medicinal plant raw material, such as Sophora japonica flower buds, Crataegus sanguinea leaves and flowers, Astragalus dasyanthus herb, Mentha piperita leaves, Arctium lappa roots.

Materials and methods. Air-dry plant raw material was harvested at the relevant phases of the growing season in 2020 (Sophora japonica flower buds at the beginning of flowering in the village Lazurne in the Skadovsk district of the Kherson region, Crataegus sanguinea leaves and flowers in the phase of mass flowering in the Kharkiv region, Astragalus dasyanthus herb and Mentha piperita leaves in the phase of mass flowering in a private area of the village Velyka Babka in the Chuhuiv district of the Kharkiv region), Arctium lappa roots at the beginning of the leaf appearance in the vicinity of the village Pishchanka in the Chuguiv district of the Kharkiv region).

The elemental composition was studied by atomic absorption spectrography with photographic registration [27]. The research was conducted at the premises of STC "Institute of Single Crystals" of the National Academy of Sciences of Ukraine (Kharkiv).

The samples of the raw material pre-treated with sulfuric acid were charred when heated in a muffle furnace (the temperature was not more than $500{ }^{\circ} \mathrm{C}$ ). Evaporation of the samples was performed from the craters of graphite electrodes in the discharge of an alternating current arc (the source of excitation of the IVS-28 type 
spectra) at a current of $16 \mathrm{~A}$ and an exposure of $60 \mathrm{~s}$. To obtain spectra and their registration on photographic plates, a DES-8 spectrograph with a diffraction grating of $600 \mathrm{ppm}$ was used. Measurements of the intensity of emission lines in the spectra of the analyzed and calibrated samples (CS) were performed using a MF-1 microphotometer.

The spectra were photographed under the following conditions: $\mathrm{AC}$ arc current $-16 \mathrm{~A}$, the ignition phase $60{ }^{\circ} \mathrm{C}$, frequency of ignition pulses -100 bits per second; analytical interval $-2 \mathrm{~mm}$; the width of the spectrograph slit $-0.015 \mathrm{~mm}$; exposition $-60 \mathrm{~s}$. The spectra were photographed in the wavelength range of $230-330 \mathrm{~nm}$.

Photographic plates were developed, dried; then photometer emission lines (nm) in the spectra of test samples and $\mathrm{C}$, as well as the background around them, were observed.

For each element, the differences of blackening between the emission line and the background $\left(\mathrm{S}=\mathrm{S}_{1}+\mathrm{f}-\mathrm{S}_{\mathrm{f}}\right)$ were calculated for the spectra of the test samples $\left(\mathrm{S}_{\mathrm{in}}\right)$ and CS (SCS). Then a calibration graph was built in the coordinates: the average value of the difference of blackening between the emission line and the background (SCS) - the logarithm of the content of the element $(\mathrm{C})$ in $\mathrm{CS}(\lg \mathrm{C})$ where $\mathrm{C}$ was expressed as a percentage. According to this graph, the content of the element in ash (a), \%, was calculated.

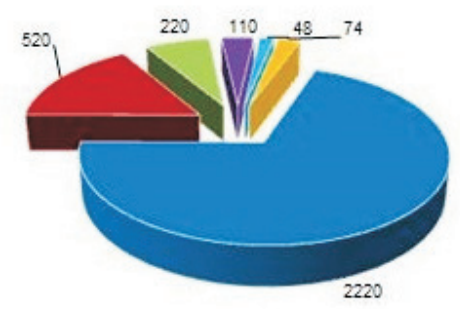

A

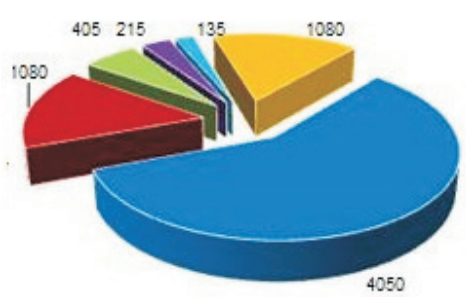

C

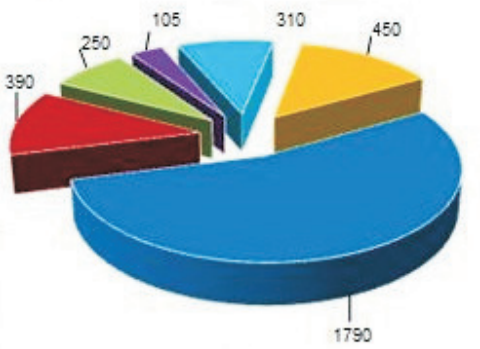

E

$\square \mathrm{K} \quad \square \mathrm{Ca} \quad \square \mathrm{Mg}$

$\square \mathrm{P}$

$\square \mathrm{Na}$

$\square \mathrm{Si}$

where: $\mathrm{m}$ - is the mass of ash, $\mathrm{g} ; \mathrm{M}$ - is the mass of the raw material taken for analysis, $\mathrm{g}$; $\mathrm{a}-$ is the content of the element in the ash, \%.

Results and discussion. After charring of samples with the medicinal herbal raw material the total ash content was determined. The results (\%) are shown in the diagram (Fig. 1).

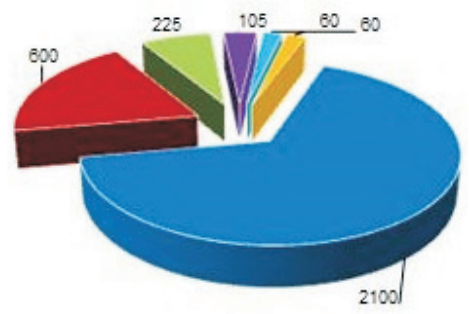

B

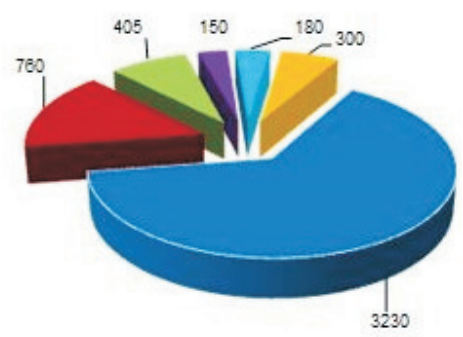

D

Fig. 2. The macronutrient composition of the types of the raw material studied (mg/100 g). A - Sophora japonica flower buds; B - Crataegus sanguinea leaves and flowers; C - Astragalus dasyanthus herb; D - Mentha piperita leaves; E - Arctium lappa roots 


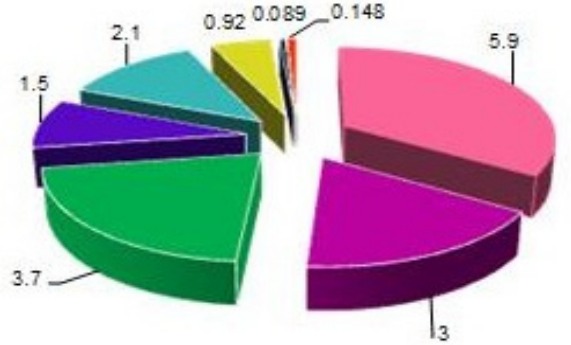

A

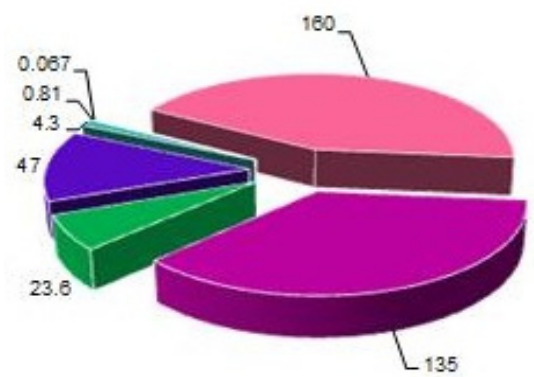

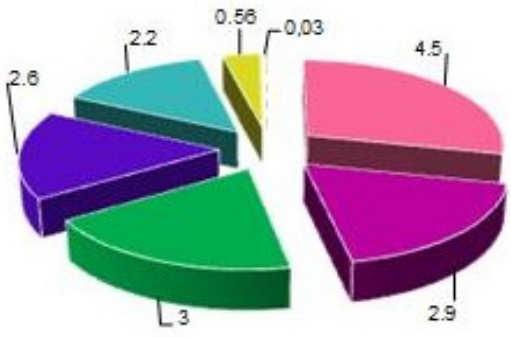

B

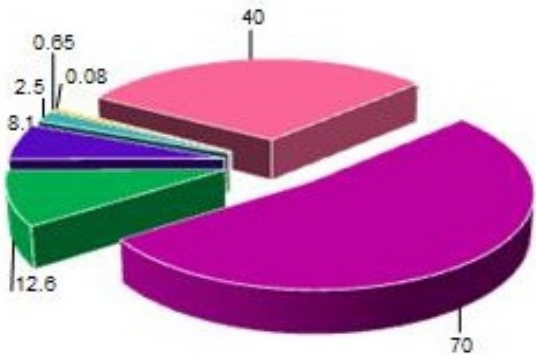

D

c

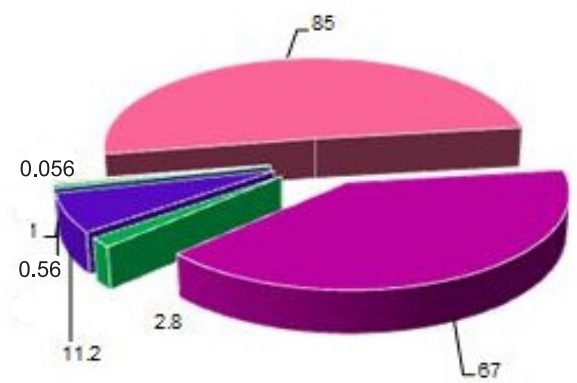

E

$\square \mathrm{Al} \quad \square \mathrm{Fe} \quad \square \mathrm{Mn} \quad \square \mathrm{Zn} \quad \square \mathrm{Sr} \quad \square \mathrm{Cu} \quad \square$ Mo

Fig. 3. The microelement composition of the types of the raw material studied (mg/100 g). A - Sophora japonica flower buds, B - Crataegus sanguinea leaves and flowers, C - Astragalus dasyanthus herb, D - Mentha piperita leaves, E - Arctium lappa roots

In total, at least 19 macro-, micro- and ultramicroelements were found in the raw material. The macronutrients found in the raw material were Potassium, Calcium, Silicon, Magnesium, Phosphorus, and Sodium. It has been proven that these elements affect blood pressure, and the drugs that contain them can be used for prophylactic purposes [28].

The results of determining the macronutrient composition of the types of the raw material studied are given in the form of diagrams in Fig. 2.

The results of studying the microelement composition of the types of the raw material are given in the form of diagrams in Fig. 3.

For the accumulation of macronutrients in the raw material the following pattern was observed: $\mathrm{K}>\mathrm{Ca}>$ $\mathrm{Mg}>\mathrm{P}>\mathrm{Si}>\mathrm{Na}$ for Sophora japonica flower buds, Crataegus sanguinea leaves and flowers; $\mathrm{K}>\mathrm{Ca}>\mathrm{Si}$ $>\mathrm{Mg}>\mathrm{P}>\mathrm{Na}$ for Astragalus dasyanthus herb; $\mathrm{K}>\mathrm{Ca}$ $>\mathrm{Mg}>\mathrm{Si}>\mathrm{Na}>\mathrm{P}$ for Mentha piperita leaves and Arctium lappa roots.

According to the results of the study, potassium dominated in the medicinal plant raw material; its content ranged from $1790 \mathrm{mg} / 100 \mathrm{~g}$ (Arctium lappa roots) to more than twice the result of $4050 \mathrm{mg} / 100 \mathrm{~g}$ (Astragalus dasyanthus herb).

In addition to potassium, the test samples contained a large amount of calcium; its content varied between $390 \mathrm{mg} / 100 \mathrm{~g}$ (Arctium lappa roots) and $1080 \mathrm{mg} / 100 \mathrm{~g}$ (Astragalus dasyanthus herb).

The content of magnesium was also quite significant and ranged from $220 \mathrm{mg} / 100 \mathrm{~g}$ (Sophora japonica flower buds) to $405 \mathrm{mg} / 100 \mathrm{~g}$ (Mentha piperita leaves).

The highest content of phosphorus was determined in Astragalus dasyanthus herb $-215 \mathrm{mg} / 100 \mathrm{~g}$. In other types of the raw material this figure was 1.5-2 times lower.

The highest sodium content was found in Arctium lappa roots $-310 \mathrm{mg} / 100 \mathrm{~g}$, while Crataegus sanguinea leaves and flowers contained five times less of this element.

Astragalus dasyanthus herb was the leader in the accumulation of silicon compared to other raw material studied $-1080 \mathrm{mg} / 100 \mathrm{~g}$.

The nickel content ranged from $0.15 \mathrm{mg} / 100 \mathrm{~g}$ in Sophora japonica flower buds to $0.08 \mathrm{mg} / 100 \mathrm{~g}$ in Crataegus sanguinea leaves and flowers, and Mentha piperita leaves. The content of elements, such as lead and cobalt, was in the range of $<0.03 \mathrm{mg} / 100 \mathrm{~g}$, and elements, 
such as cadmium, arsenic and mercury, were contained in the amount of $<0.01 \mathrm{mg} / 100 \mathrm{~g}$.

Conclusions and prospects of further research

1. The study of the elemental composition of common domestic types of the medicinal plant raw material (Sophora japonica flower buds, Crataegus sanguinea leaves and flowers, Astragalus dasyanthus herb, Mentha piperita leaves, Arctium lappa roots) by atomic absorption spectrography with photographic registration of the results showed the presence of at least 19 macro-, micro- and ultramicroelements in this raw material. It is characterized by a significant content of potassium, calcium and magnesium, which play an important role in the human body functioning in general and in the normalization of blood pressure.

2. The development of original complex medicines based on these types of the medicinal plant raw material for the prevention and treatment of diseases of the cardiovascular system, in particular arterial hypertension, can be promising.

Conflict of interest: authors have no conflict of interests to declare.

\section{REFERENCES}

1. Roger M. The Minerals You Need. USA : Safe Goods Publishing, 2011. 21 p.

2. Мызина С. Д. Биологическая роль химических элементов. Новосибирск : НГУ, 2004. 70 с.

3. Chellan P., Sadler P. J. The elements of life and medicines. The Royal Society. 2015. Vol. 373, Iss. 2037. P. 20140182. DOI: https://doi. org/10.1098/rsta.2014.0182.

4. Soetan K. O., Olaiya C. O., Oyewole O. E. The importance of mineral elements for humans, domestic animals and plants: A review. African Journal of Food Science. 2010. Vol. 4, Iss. 5. P. 200-222.

5. Струсовская О. Г., Брюклинская О. С. Определение элементного состава некоторых лекарственных растений Соловецких островов. Известия. Самарского научного Центра РАН. 2011. Т. 13, № 1 (8). С. 2038-2040.

6. Al-Fartusie F. S., Mohssan S. N. Essential Trace Elements and Their Vital Roles in Human Body. Indian Journal of Advances in Chemical Science. 2017. Vol. 5, Iss. 3. P. 127-136. DOI: https://doi.org/10.22607/IJACS.2017.503003.

7. A review on role of essential trace elements in health and disease / L. Prashanth et al. Journal of Dr. NTR University of Health Sciences. 2015. Vol. 4, Iss. 2. P. 75-85. DOI: https://doi.org/10.4103/2277-8632.158577.

8. Sigel A., Sigel H., Sigel R. K. O. Interrelations between essential metalions and human diseases. Dordrecht, The Netherlands : Springer Science and Business Media B.V. 2013. 573 p. DOI: https://doi.org/10.1007/978-94-007-7500-8.

9. Листов, С. А., Петров Н. В., Арзамасцев А. А. О содержании тяжелых металлов в лекарственном растительном сырье. Фармация 1990. № 2. C. 19-20.

10. Скальная М. Г., Нотова С. В. Макро-и микроэлементы в питании современного человека : эколого-физиологические и социальные аспекты. Москва : РОСМЭМ, 2004. 310 с.

11. World health statistics 2021: Monitoring health for the SDGs, sustainable development goals / World Health Organization. Geneva: World Health Organization. 2021. 136 p. URL: https://apps.who.int/iris/bitstream/handle/10665/342703/9789240027053-eng.pdf?sequence=1\&isAllowed=y.

12. Seventh report of the joint national committee on prevention, detection, evaluation, and treatment of high blood pressure / A. V. Chobanian et al. Hypertension. 2003. T. 42, №. 6. P. 1206-1252. DOI: https://doi.org/10.1161/01.HYP.0000107251.49515.c2.

13. Wada, O. What are Trace Elements?-Their deficiency andexcess states. The Journal of the Japan Medical Association. 2004. Vol. 47, Iss. 8. P. 351-358.

14. Dutta T. K., Mukta V. Trace elements. Medicine Update. 2012. Vol. 22. P. 353-357.

15. Geiger H., Wanner C. Magnesium in disease. Clinical Kidney Journal. 2012. Vol. 5, Iss. 1. P. 25-38. DOI: https://doi.org/10.1093/ndtplus/sfr165.

16. Иммунофармакология микроэлементов / А. В. Кудрин и др. Москва : КМК, 2000. 540 с.

17. Гравель И. В., Петров Н. В., Самылина И. А. Определение содержания тяжелых металлов в лекарственном растительном сырье. Фармация. 2008. № 7. С. 3-5.

18. Москаленко А. М., Попова Н. В. Дослідження мінерального складу сировини безсмертника приквіткового (Helichrysum bracteatum). Український біофармацевтичний журнал. 2018. № 1 (54). P. 72-76. DOI: https://doi.org/10.24959/ubphj.18.160.

19. Напраснікова Г. С., Владимирова I. М. Дослідження елементного складу деяких видів лікарських рослин, що застосовуються при гострих респіраторно-вірусних захворюваннях. Фармацевтичний журнал. 2011. № 1. С. 98-101.

20. Cholak I. S., Maksiutina N. P., Karpiuk U. V. Research of Sophora japonica 1. flower buds volatile compounds with gas-chromatography/ mass-spectrometry method. Annals of Mechnikov Institute. 2013. № 3. P. 18-23.

21. Chernikova V. V. Early diagnosis of cardiovascular disorders in patients with dystrophic myotonia. Aspirantskiy vestnik Povolzhya. 2014. № 1-2. Р. 75-77.

22. Котов А. Г. Дослідження з розробки та введення монографій на лікарську рослинну сировину до Державної фармакопеї України. Фармаком. 2009. № 1. С. 5-19.

23. Astragalus species : Insights on its chemical composition toward pharmacological applications / B. Salehi et al. Phytotherapy Research. 2020. Vol. 35, Iss. 5. P. 2445-2476. DOI: https://doi.org/10.1002/ptr.6974.

24. Investigation of the elemental composition of Sanicula Europaea 1. and Astrantia Major 1. / N. I. Legin et al. Medical and Clinical Chemistry. 2018. № 2. P. 112-116. DOI: https://doi.org/10.11603/mcch.2410-681X.2018.v0.i2.9129.

25. Андріанов К. В., Федченкова Ю. А., Хворост О. П. Вивчення елементного складу м’яти перцевої (Menta piperita). Актуальні питання фармацевтичної та медичної науки та практики. 2014. № 3 (16). C. 49-51. DOI: https://doi.org/10.14739/2409-2932.2014.3.33165.

26. Опрошанська Т. В., Хворост О. П. Вивчення макро-та мікроелементного складу кореня, листя та густих екстрактів кореня і листя лопуха великого в порівнянні з грунтом. Український журнал клінічної та лабораторної медицини. 2009. Т. 4, № 1. С. $32-34$.

27. Analysis of Macroelements Content of some Medicinal and Aromatic Plants using Flame Atomic Absorption Spectrometry (FAAS)/ I. M. Imbrea et al. Romanian Biotechnological Letters. 2016. Vol. 21, Iss. 4. P. 11642-11649.

28. Loyke H. F. Effects of elements in human blood pressure control. Biological Trace Element Research. 2002. Vol. 85, Iss. 3. P. 193-209. DOI: https://doi.org/10.1385/BTER:85:3:193. 


\section{REFERENCES}

1. Roger, M. (2011). The Minerals You Need. USA: Safe Goods Publishing, 21.

2. Myzina, S. D. (2004). Biologicheskaia rol khimicheskikh elementov. Novosibirsk: NGU, 70.

3. Chellan, P., Sadler, P. J. (2015). The elements of life and medicines. Philosophical transactions. Series A, Mathematical, physical, and engineering sciences, 373 (2037), 20140182. doi: 10.1098/rsta.2014.0182.

4. Soetan, K. O., Olaiya, C. O., Oyewole, O. E. (2010). The importance of mineral elements for humans, domestic animals and plants: A review. African Journal of Food Science, 4 (5), 200-222.

5. Strusovskaia, O. H., Briuklinskaia, O. S. (2011). Izvestiia Samarskoho nauchn. tsentra RAN, 13 (1), 2038-2040.

6. Al-Fartusie, F. S., Mohssan, S. N. (2017). Essential Trace Elements and Their Vital Roles in Human Body. Indian Journal of Advances in Chemical Science, 5 (3), 127-136. doi:10.22607/IJACS.2017.503003.

7. Prashanth, L, Kattapagari, K. K, Chitturi, R. T, Baddam, V. R, Prasad, L. K. (2015). A review on role of essential trace elements in health and disease. Journal of Dr. NTR University of Health Sciences, 4 (2), 75-85. doi: 10.4103/2277-8632.158577.

8. Sigel, A., Sigel, H., Sigel, R. K. O. (2013). Interrelations between essential metal ions and human diseases. Dordrecht, The Netherlands: Springer Science and Business Media B.V, 573. doi: https://doi.org/10.1007/978-94-007-7500-8.

9. Listov, S. A., Petrov, N. V., Arzamasczev, A. A. (1990). Farmatsiia, 2, 19-20.

10. Skalnaia, M. H., Notova, S. V. (2004). Makro-i mikroelementy v pitanii sovremennogo cheloveka: ekologo-fiziologicheskie i soczialnye aspekty. Moscow: Rosmem, 310.

11. World Health Organization. (2021). World health statistics 2021: Monitoring health for the SDGs, sustainable development goals. Geneva: World Health Organization. Available at: https://apps.who.int/iris/bitstream/handle/10665/342703/9789240027053-eng.pdf?sequence=1\&isAllowed=y.

12. Chobanian, A. V., Bakris, G. L., Black, H. R., Cushman, W. C., Green, L. A., IzzoJr, J. L. et al. (2003). Seventh report of the joint national committee on prevention, detection, evaluation, and treatment of high blood pressure. Hypertension, 42 (6), 1206-1252. doi: https://doi.org/10.1161/01.HYP.0000107251.49515.c2.

13. Wada, O. (2003).What are Trace Elements? - Their deficiency and excess states. The Journal of the Japan Medical Association, 129 (5), $607-612$.

14. Dutta, T. K., Mukta, V. (2012). Trace elements. Medicine Update, 22, 353-357.

15. Geiger, H., Wanner, C. (2012). Magnesium in disease. Clinical Kidney Journal, 5, 25-38. doi:10.1093/ndtplus/sfr165.

16. Kudrin, A. V., Skalnyj, A. V., Zhavoronkov, A. A., Skalnaya, M. G., Gromova, O. A. (2000). Immunofarmakolohiia mikroelementov. Moscow, 537.

17. Gravel, I. V., Petrov, N. V., Samylina, I. A. (2008). Farmatsiia, 7, 3-5.

18. Moskalenko, A. M., Popova, N. V. (2018). Ukrayinskyi biofarmatsevtychnyi zhurnal, 1 (54). doi: 10.24959/ubphj.18.160.

19. Naprasnikova, H. S., Vladimirova, I. M. (2011). Farmatsevtychnyi zhurnal, 1, 98-101.

20. Cholak, I. S., Maksiutina, N. P., Karpiuk, U. V. (2013). Research of Sophora japonica L. flower buds volatile compounds with gaschromatography/mass- spectrometry method. Annals of Mechnikov Institute, 3, 18-23.

21. Chernikova, V. V. (2014). Early diagnosis of cardiovascular disorders in patients with dystrophic myotonia. Aspirantskii vestnik Povolzh'ia, 1-2, 75-77.

22. Kotov, A. H. (2009). Farmakom, 1, 5-19.

23. Salehi, B., Carneiro, J. N. P., Rocha, J. E., Coutinho, H. D. M., Morais Braga, M. F. B., Sharifi-Rad, J. et al. (2020). Astragalus species: Insights on its chemical composition toward pharmacological applications. Phytother Res. doi: 10.1002/ptr.6974.

24. Legin, N. I., Koliadzhyn, T. I., Grytsyk, L. M., Grytsyk, A. R. (2018). Investigation of the elemental composition of Sanicula Europaea L. and Astrantia Major L. Medical and Clinical Chemistry, 2, 112-116. doi: https://doi.org/10.11603/mcch.2410-681X.2018.v0.i2.9129.

25. Andrianov, K. V., Fedchenkova, Yu. A., Khvorost, O. P. (2014). Aktualni pytannia farmats. ta med. nauky ta praktyky, 3 (16), $49-51$. doi: https://doi.org/10.14739/2409-2932.2014.3.33165.

26. Oproshanska, T. V., Khvorost, O. P. (2009). Ukrainskyi zhurnal klinichnoi ta laboratornoi medytsyny, 4 (1), 32-34.

27. Imbrea, I. M., Radulov, I., Romanian, A. L. N. (2016). Analysis of Macroelements Content of some Medicinal and Aromatic Plants using Flame Atomic Absorption Spectrometry (FAAS). Biotechnological Letters, 21 (4), 11642-11649.

28. Loyke, H. F. (2002). Effects of elements in human blood pressure control. Biol Trace Elem Res, 85 (3), 193-209. doi: https://doi. org/10.1385/BTER:85:3:193.

\section{Information about authors:}

Zudova Ye. Yu., postgraduate student of the Department of Chemistry of Natural Compounds and Nutritiology, National University

of Pharmacy of the Ministry of Health of Ukraine. E-mail: evgeniya97zudova@gmail.com. ORCID: https://orcid.org/0000-0003-3772-016X

Khvorost O. P., Doctor of Pharmacy (Dr. habil.), professor of the Department of Chemistry of Natural Compounds and Nutritiology,

National University of Pharmacy of the Ministry of Health of Ukraine. E-mail: khvorost09101960@gmail.com.

ORCID: https://orcid.org/0000-0002-9534-1507

Відомості про авторів:

Зудова Є. Ю., аспірантка кафедри хімії природних сполук та нутриціології, Національний фармацевтичний університет

Міністерства охорони здоров’я України. E-mail: evgeniya97zudova@gmail.com. ORCID: https://orcid.org/0000-0003-3772-016X

Хворост О. П., докторка фармац. наук, професорка кафедри хімії природних сполук та нутриціології, Національний фармацевтичний

університет Міністерства охорони здоров'я України. E-mail: khvorost09101960@gmail.com. ORCID: https://orcid.org/0000-0002-9534-1507 Сведения об авторах:

Зудова Е. Ю., аспирантка кафедры химии природных соединений и нутрициологии, Национальный фармацевтический университет

Министерства здравоохранения Украины. E-mail: evgeniya97zudova@gmail.com. ORCID: https://orcid.org/0000-0003-3772-016X

Хворост О. П., доктор фармац. наук, профессор кафедры химии природных соединений и нутрициологии, Национальный

фармацевтический университет Министерства здравоохранения Украины. E-mail: khvorost09101960@gmail.com.

ORCID: https://orcid.org/0000-0002-9534-1507 